\title{
The Need for the Incorporation of Ergonomics into Curriculum of the Technical and Vocational Education and Training for Teacher/Trainer Professionalization
}

\author{
Jamilu Mustapha Chedi \\ Department of Vocational and Technology Education, Faculty of Technology Education, \\ Abubakar Tafawa Balewa University, Bauchi, Nigeria \\ aljamil7@yahoo.com
}

\begin{abstract}
Ergonomics has to do with maximizing user's/worker's comfort, safety and health, productivity and efficiency while in the other hand Technical and Vocational Education and Training (TVET) concern with knowledge, skills, attitude, and occupation. Ergonomics is yet to have the recognition it deserves in TVET. In engineering and technology, ergonomics used to be taught as a course of study while in TVET is used to be taught as a topic and not be taught at all. "Curricula do not meet professionalism" these are one of the challenges of TVET teacher/trainer professionalization. TVET teacher/trainer has 'dual professionalism' that is subject specialism and pedagogy. The paper intends to analyze and discuss the previous documents and findings to come up with ways forward in the incorporation of ergonomics in TVET curriculum. The paper highlights on the ergonomics in brief, ergonomics in TVET curriculum, relationship of Ergonomic, TVET, Labor and Professionalism, finally recommendations and conclusion where given.
\end{abstract}

Index Terms - ergonomics, TVET, curriculum, incorporation and professionalism

\section{Introduction}

The paper is a documentary research based paper, in other wards is the document or literature research paper, and focuses on TVET curriculum, how to incorporation ergonomics fields/course in TVET curriculum. Also, discussed on the present and future challenges of the TVET professionalism and labor market, relationship of Ergonomic, TVET, Labor and Professionalism. Ergonomics deals with the application of information about human behavior, capabilities and limitations to the design of systems, machines, tools, tasks or jobs and environments for productive, safe and effective human use [1]. The goal of ergonomics is to ensure a good fit between the workers and their job, thereby maximizing worker's comfort, safety and health, productivity and efficiency. The term initially introduced into the literature by the Polish natural scientist Jastrzebowski in 1857 [2]. Later, the term ergonomics was independently reinvented and formally established by Murrell in 1949 [3]. Ergonomics activities and researches in Industrial Developing Countries (IDCs) mainly began during the early 1960s [4]. Even though, back to 1949, the national ergonomics society of England was founded. Therefore, the relevance of ergonomics in TVET by looking at the definition shows that the ergonomics will make a vital role in improving and standardizing the TVET.

Whereas, Technical and vocational education and training (TVET) as cited by] [5] in (Green, Hodgson, and Sakamoto, 2000): Refers to a range of learning experiences which are relevant to the world of work and which may occur in a variety of learning contexts, including educational institutions and the workplace. It includes learning designed to develop the skills for practicing particular occupations, as well as learning designed to prepare for entry or re-entry into the world of work in general. By definition, TVET thus covers a diverse spectrum of learning activities and this shows, that is dynamics and changing with the needs of today's and features situation.

The definition of curriculum proposed by Cedefop is the inventory of activities implemented to design, organize and plan an education or training action, including the definition of learning objectives, content, methods (including assessment) and material, as well as arrangements for training teachers and trainers [6].

\section{Ergonomics in Brief}

Ergonomics derived from the Greek words 'ergon', which means 'work' and 'nomos', which means 'laws', ergonomics literally means the laws of the work [7]. Human factors are also the term used in USA and few countries, while ergonomics use in Europe and the rest of the world.

The formal definition of ergonomics, approved by the International Ergonomics Association (IEA), reads as follows: Ergonomics (or human factors) is the scientific discipline concerned with understanding of the interactions among humans and other elements of a system, and profession that applies theory, principles, data and methods to design, in order to optimize human well-being and overall system performance [8].

In general, ergonomics is about the user, the product and the task, in other word is user-cantered design. Pheasant and Haslegreve [9], said, "Fitting the job to the worker involves consideration of health and quality of working life just as much as of productivity and efficiency and quality of performance are influenced by all three element."

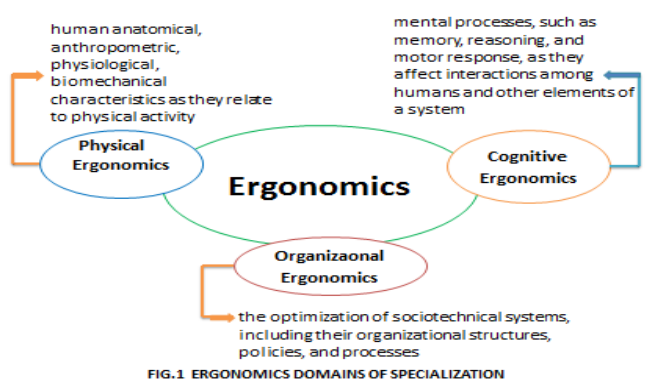

Ergonomics is a diversified field of study which involves many areas of study due to its interdisciplinary approach and applied nature. Ergonomics draw knowledge from various fields in the human sciences and technology, 
including anthropometrics, physiology, psychology, toxicology, mechanical engineering, industrial design, information technology and management.

\section{TVET Curriculum}

Ever since the term "curriculum" was added to educators' vocabularies, it has seemed to convey many things to many people. If we are to go by history, one of the earliest forms of systematic curriculum building in vocational education may be attributed to Victor Della Vos, director of the Imperial Technical School of Moscow. At the Philadelphia Centennial Exposition of 1876, Della Vos demonstrated a new approach to teaching the mechanical art that 'become a catalyst for vocational education in United State.' [10]. Using these principles, Della Vos set up separate shops in the areas of carpentry, joinery, blacksmithing and metal turning. Gradually, TVET curriculum faces changes due to the so many demands and needs of situations.

According to [11] stated that, "Wheeler defined curriculum as the "planned experiences offered to the learner under the guidance of the school." Also, in [12] reported that, Isenegger classifies the curriculum concept into

two understandings. First, curriculum is a document, a codified form of educational intentions. This understanding is widely used in German-speaking areas. Second, curriculum is the totality of (planned) activities influencing the teaching and training process. This understanding is more common in English-speaking areas.

However, the impact of curriculum is beyond the school, the students were trained to become useful member or citizens of their respective societies or countries.

A number of questions have been raised about TVET curriculum, as Kerre [13] said, "A major challenge in the preparation of TVET teachers is of a curricular nature. What curriculum shall they impart? And consequently what curriculum should they pursue?' Also, an observation was made that, 'Curriculum is increasingly seen by stakeholders as a dynamic framework guiding teaching and learning processes and as a steering mechanism for quality [12].

\section{Incorporation of Ergonomics in TVET Curriculum}

One of the common observation is the saying that, "Curricula do not match industry needs" these indicate the need for continues reviewing and updating the TVET curriculum.

In November 2004, the UNESCO International Meeting on Innovation and Excellence in TVET Teacher Education took place in Hangzhou/China and the main aim of the conference is to improve the quality of TVET at international level. While, in 2005, another conference, titled 'Development and Implementation of a Master Degree Standard for Teacher and Trainer Education in TVET" took place at the University of Tianjin in China. The two conferences come up with new Master degree in TVET such as, The Otto-von-Guericke-University Magdeburg, in Germany, has developed a M.Sc. programme which operates over four semesters in collaboration with Southeast University (China), Tianjin University (China), and the University of Technology Education (Vietnam). The course is titled "Technical and Vocational Education and Training" and leads to a joint award.
Looking at Institute of Vocational Instructors at Tongji University, China as our model of analysis which was founded in 1994 and in 2001 the Institute was allowed to offer a Master's education in pedagogy. The Institute offers two kinds of Master's degree, one is Master of Pedagogy; the other a Master of Engineering with three research majors: civil, mechanical, and electronic (refer to Table 1).

Table 1. Curricula Structure

\begin{tabular}{|c|l|c|}
\hline $\begin{array}{c}\text { Compulsory Course in } \\
\text { engineering }\end{array}$ & $\begin{array}{l}\text { Optional Course in } \\
\text { engineering }\end{array}$ \\
\cline { 1 - 2 } $\begin{array}{c}\text { Compulsory Course in } \\
\text { pedagogy }\end{array}$ & $\begin{array}{l}\text { Optional Course in } \\
\text { pedagogy }\end{array}$ \\
\hline Public and basic course & \\
\hline
\end{tabular}

Source: Jianrong and Yanyan,[14].

TABle 2. Curriculum FOR Major of Pedagogy

\begin{tabular}{|c|c|c|c|}
\hline \multicolumn{2}{|l|}{ Courses } & $\begin{array}{l}\text { Study } \\
\text { hour }\end{array}$ & $\begin{array}{l}\text { Credit } \\
\text { Point }\end{array}$ \\
\hline \multirow{3}{*}{$\begin{array}{l}\text { Public and } \\
\text { Basic } \\
\text { Courses }\end{array}$} & $\begin{array}{l}\text { Selected Marxist Classic } \\
\text { Works }\end{array}$ & 54 & 2 \\
\hline & $\begin{array}{l}\text { Theory and Practice of } \\
\text { Socialism }\end{array}$ & 36 & 1 \\
\hline & $\begin{array}{l}\text { First Foreign Language } \\
\text { (basic course) }\end{array}$ & 180 & 3 \\
\hline \multirow{6}{*}{$\begin{array}{l}\text { Compulsory } \\
\text { Courses }\end{array}$} & $\begin{array}{l}\text { First Foreign Language } \\
\text { (specialized course) }\end{array}$ & 36 & 2 \\
\hline & $\begin{array}{l}\text { Educational Research } \\
\text { Methods }\end{array}$ & 54 & 3 \\
\hline & $\begin{array}{lll}\text { Outlines of } & \text { TVET } \\
\text { Curricula } & & \end{array}$ & 54 & 3 \\
\hline & $\begin{array}{l}\text { Development of Modern } \\
\text { Teaching Media }\end{array}$ & 36 & 2 \\
\hline & Vocational Pedagogy & 54 & 3 \\
\hline & $\begin{array}{l}\text { Comparison of TVET in } \\
\text { China and Germany }\end{array}$ & 54 & 3 \\
\hline & $\begin{array}{ll}\text { Second } & \text { Foreign } \\
\text { Language } & \end{array}$ & 108 & 2 \\
\hline & $\begin{array}{lr}\text { Foundations } & \text { of } \\
\text { Computer } & \text { Network } \\
\text { Technology } & \end{array}$ & 36 & 2 \\
\hline & Psychology on TVET & 54 & 3 \\
\hline
\end{tabular}




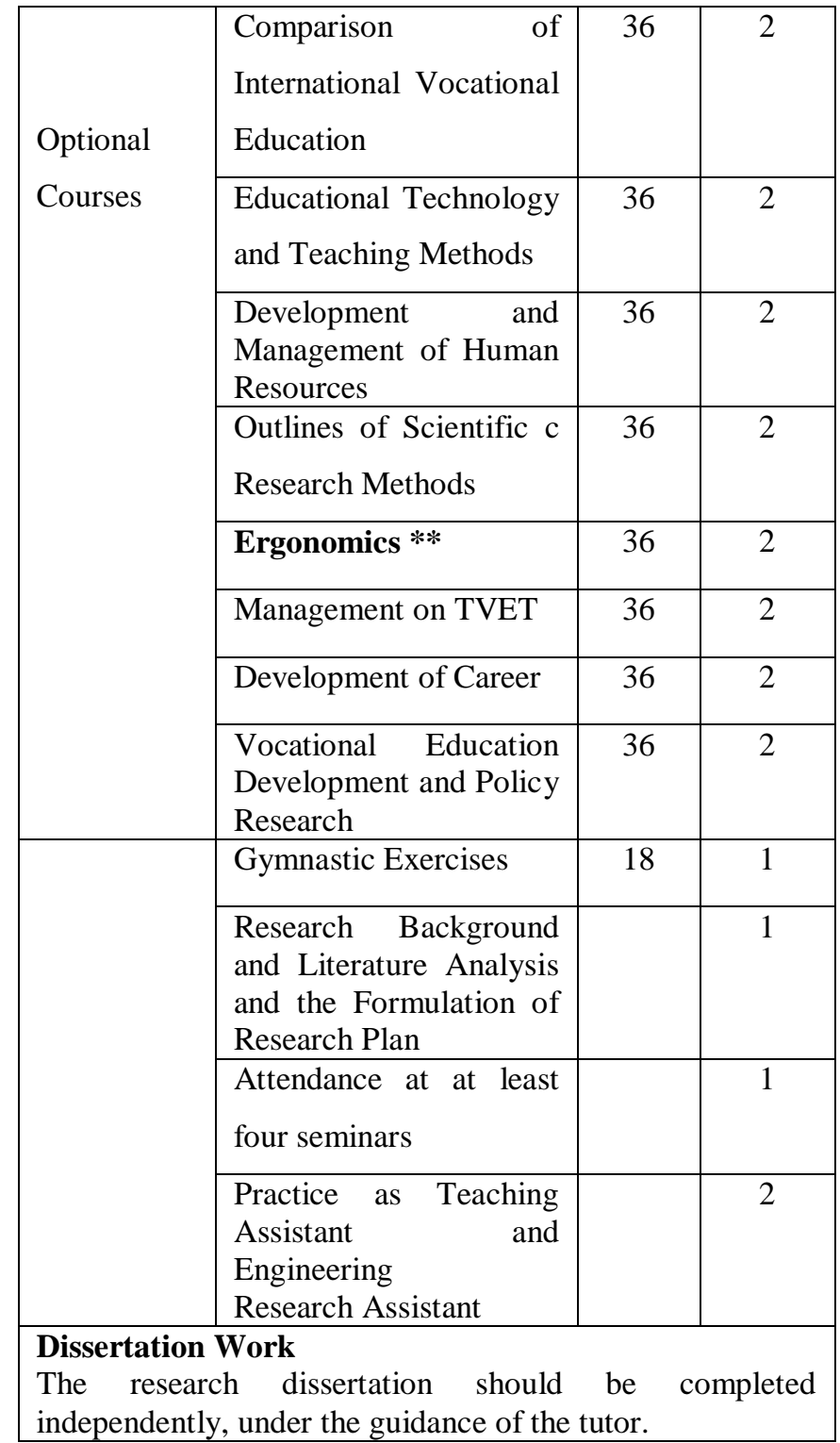

Source: Jianrong and Yanyan, [14]

Table 2 shows how Ergonomics was integrated in to Curricula for Major of Pedagogy with 36 hours 2 credits which is also the same is applied to engineering option. Therefore, it is in line with international standard that, in particular TVET curriculum developers should make changes in our TVET institutions to review the TVET curriculum so as to meet the skills required and labor market. In support of these demands, [15] said,

'The method resulting from the re-thinking of the role of TVET in the knowledge-based globalized society is called the functional analysis method. It integrates three key components namely; i) the requirements of the employment, both current and anticipated, ii) a flexible curricula structure and content that can be modified to the changing situation, and iii) the assessment specification that links the first two."

As [16] stated that, 'only by improving the quality of teachers of vocational education, can we develop the quality of talent fostering and cultivate the characteristics of vocational education."'

\section{Present and Future Challenges of TVET Professionalism}

Professionalism is the term with so many definitions, the Encarta Dictionary [17] defined professionalism as professional standard: the skill, competence, or character expected of a member of highly trained profession. Experts are yet to reach the acceptable definition of professionalism and this is one of the challenges as stated by Evans [2008] [18] 'Yet still the very substance of professionalism - what, precisely professionalism is and how it is constituted remains under-examined'.

Another challenge for TVET professionalism is the dual professionalism, that is area of specialization and pedagogy as it has being stated by [19]

Indeed, for the majority of teachers and trainers, teaching in LLS (lifelong learning sector) is a second or third career. As such, they are often professionals in their own field before they start their teaching career. For example, you could be a nurse working in a hospital or perhaps a bricklayer working in construction, before considering teaching your subject. There are two components of your professionalism: your subject specialism and the pedagogy related to that area. This is what is referred to as 'dual professionalism' and both are equally important in your role as a tutor or trainer. It is therefore essential that both these areas are considered when you address your CPD (Continuing Professional Development).

Previous researches shown that, there are many challenges facing the TVET professionalism, according to [20] state that, "the core of the problem, 'Technical and Vocational Education and Training (TVET) is concerned with the acquisition of knowledge and skills for the world of work. (UNESCO-UNEVOC) but TVET does not provide the competences needed by the economy and needed by the individual to make a living.' This shows the need for standard in TVET, and when there is standard the next is the professionalism.

The Helsinki workshop have identified the challenges to the VTE teacher profession as, "it is fairly easy to identify transnational challenges in the "professionalization of teachers'. However, in order to find solutions and identify good practices to meet these challenges, more dialogue and research are needed [21]. And that is why the need arise to look at previous, present and future situation of the TVET challenges and problems so as to identify the way forward.

\section{Ergonomic, TVET, Labour and Professionalism}

There is strong relationship between TVET and labor in which to some extent is more of labor oriented and Netherlands Initiative for Capacity development in Higher Education NICHE [22] stated that, TVET is extremely wellpositioned to contribute to global development, participation and interaction. It is especially flexible in nature (which, for example, allows broad participation of people requiring skills training) and is greatly oriented to the labor market (which allows appropriate adaptation to changing trends in 
the local, national and global labor market and economic sectors).

Due to the importance of Ergonomic in the labor, a book has being published in collaboration between International Labor Office (ILO) and International Ergonomics Association (IEA) called: Ergonomic checkpoints. And important areas that directly or indirectly effect TVET were discussed such as: "Materials storage and handling, Hand tools, Machine safety, Workstation design, Lighting Premises, Hazardous substances and agents, Welfare facilities, Work organization,".

Another area of great concern is the skills gaps; a lot of TVET professionals may have the skills but due to the lack of ergonomic awareness may result to deficiency or inadequacy of skills. According to [23] reported that;

Strietska-Ilina (in Cedefop, Strietska-Ilina, 2008) refers to skills gaps to describe the qualitative mismatch between the supply or availability of human resources and the requirements of the labor market. Skills gaps exist when workers have inadequate skill types/levels to meet their employers 'objectives or when new entrants to the labor market are apparently trained and qualified for occupations but still lack some of the skills required.

International Labor Office in collaboration with the International Ergonomics Association [24] confirmed that:

'Experience is being gained in applying ergonomics to workplaces in different sectors and industrial situations in both developed and developing countries, with tangible results in the reduction of occupational accidents, work-related diseases and major industrial accidents, as well as improvements in unsatisfactory working conditions."

The above citation shows the relationship on how ergonomic plays a vital role in improving and standardizes the TVET. In summary, when individuals possessed knowledge in ergonomics, it will in turn enhance their skills and competence within their field of study/expertise as well as creating more opportunities in the labor market since labor market need dynamics skills. It is widely acknowledged that, members should ensure that vocational education and training systems are developed and strengthened to provide appropriate opportunities for the development and certification of skills relevant to the labor market [25].

Generally, ergonomics will contribute in providing the skills relevant to industries and labor such as safety, productivity, usage and organization of workplace, the task and some element of the design for users comport.

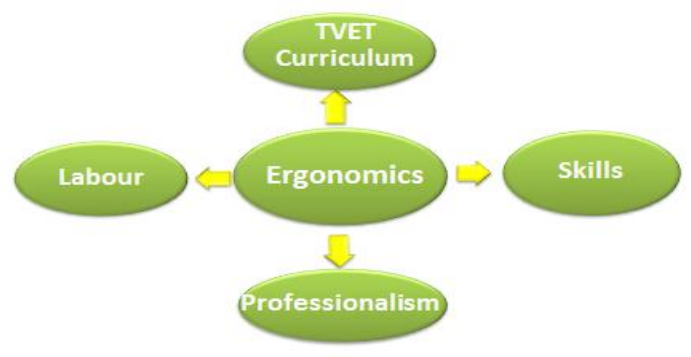

FIG. 2 Ergonomic, TVET, Labour and Professionalism

The above figure illustrates the relationship and role of ergonomics with other elements. This shows that, there is an ergonomics need in TVET curriculum, Skills, Labor and Professionalism.

\section{Recommendations}

- To make TVET more of professionalism, there is need to incorporate ergonomics in TVET Curriculum regardless of the level of studies (i.e. at Degree or Masters Level)

- It has been observed that knowledge of workplace is one of the prerequisite of improving TVET occupational skills and competence respectively. And to meet this kind of demands it becomes necessary to introduce ergonomics into curriculum of TVET.

- Extra careful has to be taken into development and implementation of the curriculum of ergonomics due to its nature as more scientific and practical oriented field of study.

- TVET curriculum developers and professionals should review the curriculum to meet job opportunities and labor market demand through the full contents of ergonomics.

- For the sustainable industrial development and professionalism TVET curriculum should provide ways of incorporating working relations within the diversify society.

\section{Conclusions}

The paper review related previous research and documents available in which it discovered that, in meeting the today's and tomorrow's need and labor market demand, there is an urgent demands towards the continuous incorporating new and existing fields/course of studies in to TVET curriculum, such as Ergonomics. It proved that, as some other institutions in the world and many fields of studies incorporate ergonomic, it become necessary to adapt the new development, to achieve new skills and improve towards meeting the challenges of the TVET standard and professionalism.

Hence, the study shows the importance and role of ergonomics in other fields of profession such as engineering and Industrial Design it is expected to be applied to TVET professionals to meet the demands needed for the standard professionalism. 


\section{References}

[1]. A. Chaplains, "Some Reflections on Progress." in Proc. Human Factors $29^{\text {th }}$ Annu. Meeting." Santa Monica. 1985, USA. $1-8$

[2]. R. S. Bridger, Introduction to Ergonomics. 2nd Edition. London: Taylor and Francis. Brooke, J. 1996. SUS: A 'Quick \& Dirty’ Usability Scale. In P.W. Jordan, B. Thomas, B.A.

[3]. O.G.Edholm and K.F.H. Murrell ''The Ergonomics Research Society: A History, 1949-1970. Ergonomics'”. 1974 London: Taylor and Francis

[4]. S. Banerjee, "Studies on Energy Metabolism." Indian Council of Medical Research. New Delhi. Special Rep.. 43:1-31. 1962

[5]. R. MacLean and D. Wilson "International Handbook of Education for the Changing World Springer Science+Businessmedia B.V. 2009, [Online].Available: DOI 10.1007/978-1-4020-5281-1_XII.4.C

[6]. Cedefop, (2008): 'Terminology of European education and training policy A selection of 100 key terms" Luxembourg: Publication Office. [Online]. Available: http://www.cedefop.europa.eu/etv/Upload/Information_resource s/Bookshop/369/4064_en.pdf, Accessed 12.4.2010

[7]. T.J, Sluchak, "Ergonomics: Origins, Focus and Implementation Considerations." AAOHN Journal. 40(3): 105-11. [Online]. Available: http://www.ncbi.nlm.nih.gov/pubmed/1550620 Accessed 26/07/2014]

[8]. J. Dul and B. Weerdmeester, Ergonomics for beginners Boca Ranto, FL: CRC Press, 2008.

[9]. P.Stephen and H. M. Christine, Bodyspace Anthropometry, Ergonomic and the Design Work. Boca Raton USA: CRC Press, 2006.

[10]. C. R. Finch and J. R. Crunkilton, Curriculum Development in Vocational and Technical

Education: Planning, Content, and Implementation. $2^{\text {nd }}$ Edition, Massachusetts: Allyn and Bacon. 1979.

[11]. B. Stephen, Vocational Education: Purposes, Traditions and Prospects. Hardcover. Springer London and New York, 2011.

[12]. Cedefop (2010): Research paper No 6 Learning outcomes approaches in VET curricula; $A$ comparative analysis of nine European countries. Luxembourg: Publications Office of the European Union. [Online]. Available: www.cedefop.europa.eu/files/5506 en.pdf

[13]. W. B. Kerre, "Science and Technology Teacher Education in Africa: Issues in the promotion of scientific and technological literacy, " Centre for Teacher Education, European Journal of Social Sciences, 10(4) 60I-605. [Online]. Available: http:// www.portal.unesco.org/education/en/files/52553/11725002665 Kerre.pdf/Kerre.pdf Accessed: 23/08/2014]

[14]. Z. Jianrong and L. Yanyan. Problems and Perspectives of Master's Degree Programmes for In-service TVET Teachers: A Case Study at Tongji University, " in TVET Teacher Edu. on the Threshold of Internationalization, Frank Bünning and Zhi-Qun Zhao (eds.) Bonn, Germany. 2006 ch.1, pp 81- 90

[15]. O. Oleynikova, "Curriculum development: the Russian perspective, "Int. J. of vocational edu. and training” vol. 21 no. 1, pp75 - 79, Jun 2013

[16]. F. Q. Zhang, Master's Degree for Secondary Vocational School Teachers: a New Mode to Train Teachers of Vocational Edu. in China. [Online]. Available: http://www.unevoc.unesco.org/fileadmin/user upload/docs/1We bVersion Initiative to foster Chinese TVET and TVET Tea cher Training.pdf Accessed: 30/07/2014]

[17]. Encarta Dictionary (2010)

[18]. E. Linda, "Professionalism, professionality and the development of education professionals". Brit. J. of Educational Stud., 56 (1). pp. 20-38. 2008

[19]. D. Vicky and T. Jonathan, "Contemporary Issues in Lifelong Learning." Open University Press, McGraw- Hill Education, Berkshire and New York. 2010

[20]. D. Joachim, "Professional Development for TVET Lecturers." FET Conference; Bloemfontein, South Africa. [Online].Available: http://www.vvob.be/southafrica/sites/default/files/joachim_dittri ch.pdf Accessed: 14/08/2011]

[21]. C. Pia, H. Auli , and V. Kristiina, "Professionalization of VET teachers for the future." [Online].Available:
http://www.cedefop.europa.eu/EN/Files/5156_en.pdf Accessed $15 / 08 / 2014]$

[22]. NICHE, "strategy on Technical and Vocational Education and Training (TVET)." Netherlands Initiative for Capacity development in Higher Education, NICHE. July 2010

[23]. CEDEFOP, "Learning outcomes approaches in VET curricula" 2009 [Online].Available: www.cedefop.europa.eu/EN/Files/5506_en.pdf .

[24]. Int, Labor Office in collaboration with the Int. Ergonomics Assoc. (2010). Ergonomic checkpoints: Practical and easy-toimplement solutions for improving safety, health and working conditions. Int. Labor Office, CH-1211 Geneva 22, Switzerland

[25]. Education International, "Literature Review Vocational Education and Training" 12 October 2009 [Online].Available: http://download.eiie.org/Docs/WebDepot/091213 VET Literatu re EDITED\%20AA.pdf Accessed: 20/08/2014] 